\title{
Water-Soluble [2.2]Paracyclophane Chromophores with Large Two- Photon Action Cross Sections
}

Han Young Woo, Janice W. Hong, Bin Liu, Alexander A. Mikhailovsky, Dmitry Korystov and Guillermo C. Bazan*

Mitsubishi Chemical Center for Advanced Materials, Department of Materials, Institute for Polymers and Organic Solids, University of California, Santa Barbara, California 93106

\section{Synthesis and Characterization}

Aniline was freshly purified by vacuum distillation. All other commercial chemicals were purchased from Aldrich and used as received. ${ }^{1} \mathrm{H}$ and ${ }^{13} \mathrm{C}$-NMR spectra were collected on a Varian Unity $400 \mathrm{MHz}$ (or $200 \mathrm{MHz}$ ) spectrometer. Mass spectrometry analyses were performed by UC, Santa Barbara, Mass Spectrometry Laboratory. The UV-vis absorption spectra were recorded on a Shimadzu UV-2401 PC diode array spectrometer. Photoluminescence spectra were obtained on a PTI Quantum Master fluorometer equipped with a Xenon lamp excitation source.

The synthetic details for the intermediates, neutral $(\mathbf{1 N} \sim \mathbf{3 N})$ and ionic $(\mathbf{1 C} \sim \mathbf{3 C})$ [2.2]paracyclophane chromophores described in Scheme 1 are given below.

N,N-Bis(6'-chlorohexyl)-4-amino-benzaldehyde (4). Using a modified literature method, ${ }^{1}$ the reaction of aniline with 6-chloro-1-hexanol in butanol provided N,N-bis(6hydroxyhexyl)-aniline in $70 \%$ yield. A $100 \mathrm{~mL}$ two-necked flask containing $15 \mathrm{~mL}$ of dry DMF was cooled down to $0{ }^{\circ} \mathrm{C}$ with an ice bath. To this solution, $4.7 \mathrm{~g}(30.7 \mathrm{mmol})$ of phosphorous oxychloride was added dropwise and the mixture was stirred for $30 \mathrm{~min}$ at 0 ${ }^{\circ} \mathrm{C} .3 \mathrm{~g}$ (10.2 mmol) of N,N-bis(6-hydroxyhexyl)-aniline in dry DMF (15 mL) was added to the above solution and heated to $90{ }^{\circ} \mathrm{C}$ for $2 \mathrm{hrs}$. The reaction solution was cooled down to room temperature, poured into ice water and neutralized to $\mathrm{pH} 6-8$ with saturated $\mathrm{NaOH}$ aqueous solution. The resulting solution was extracted with dichloromethane and then dried over magnesium sulfate. The crude compound was purified by silica gel column chromatography (ethyl acetate/hexane $=1 / 5)$ to yield $2.3 \mathrm{~g}(63 \%)$ of pure light brown oil, 4. ${ }^{1} \mathrm{H}-\mathrm{NMR}\left(200 \mathrm{MHz}, \mathrm{CDCl}_{3}\right): \delta 9.71(\mathrm{~s}, 1 \mathrm{H},-\mathrm{CHO}), 7.71(\mathrm{~d}, 2 \mathrm{H}, \mathrm{J}=9.0 \mathrm{~Hz}), 6.64(\mathrm{~d}$, $2 \mathrm{H}, \mathrm{J}=9.0 \mathrm{~Hz}), 3.55\left(\mathrm{t}, 4 \mathrm{H},-\mathrm{CH}_{2} \mathrm{Cl}, \mathrm{J}=6.6 \mathrm{~Hz}\right), 3.35\left(\mathrm{t}, 4 \mathrm{H},-\mathrm{NCH}_{2^{-}}, \mathrm{J}=7.6 \mathrm{~Hz}\right), 1.80(\mathrm{~m}$, $4 \mathrm{H}), 1.68-1.37(\mathrm{~m}, 12 \mathrm{H}) .{ }^{13} \mathrm{C}-\mathrm{NMR}\left(100 \mathrm{MHz}, \mathrm{CDCl}_{3}\right): \delta$ 190.2, 152.7, 132.5, 124.9, $110.9,51.1,45.2,32.7,27.2,26.9,26.5$. HRMS (EI): $\mathrm{m} / \mathrm{z}=357.1617\left(\mathrm{M}^{+}\right), \Delta=2.6 \mathrm{ppm}$.

N-(6'-Chlorohexyl)carbazole-3-carboxaldehyde (5). Sodium hydride (0.86 g, 35.8 mmol) was added to a two-necked flask containing carbazole $(4.0 \mathrm{~g}, 23.9 \mathrm{mmol})$ and 1,6dibromohexane $(29.2 \mathrm{~g}, 120 \mathrm{mmol})$ in $100 \mathrm{~mL}$ of anhydrous THF. This mixture was refluxed under nitrogen for 2 days. The reaction mixture was cooled down to room temperature and extracted with ethyl acetate. The unreacted 1,6-dibromohexane and 
carbazole were removed by vacuum distillation $\left(100{ }^{\circ} \mathrm{C} / 16 \mathrm{mmHg}\right)$ and column chromatography (ethyl acetate/hexane $=1 / 30)$, respectively. Pure $\mathrm{N}-(6-$ bromohexyl)carbazole was obtained as a white crystalline solid $(4 \mathrm{~g}, 51 \%)$. The $100 \mathrm{~mL}$ flask containing $30 \mathrm{~mL}$ of dry DMF was cooled down to $0{ }^{\circ} \mathrm{C}$. Phosphorous oxychloride (4.4 g, $28.7 \mathrm{mmol})$ was added dropwise, while maintaining the temperature below $5{ }^{\circ} \mathrm{C}$. The reaction mixture was stirred for $30 \mathrm{~min}$. $1.9 \mathrm{~g}(5.75 \mathrm{mmol})$ of $\mathrm{N}-(6-$ bromohexyl)carbazole in $20 \mathrm{~mL}$ of dry DMF was added to the above solution and the temperature was slowly increased to $90{ }^{\circ} \mathrm{C}$. After the solution was heated for 2 days, it was cooled down to room temperature and poured into cold water. The $\mathrm{pH}$ of the solution was adjusted to around 7 with aqueous $\mathrm{NaOH}$ solution. The product was extracted with dichloromethane, dried over magnesium sulfate, and purified by silica gel column chromatography (ethyl acetate/hexane $=1 / 5$ ). A light brown crystalline solid was obtained $(1.3 \mathrm{~g}, 72 \%) .{ }^{1} \mathrm{H}-\mathrm{NMR}\left(200 \mathrm{MHz}, \mathrm{CDCl}_{3}\right): \delta 10.1(\mathrm{~s}, 1 \mathrm{H},-\mathrm{CHO}), 8.62(\mathrm{~m}, 1 \mathrm{H}), 8.17(\mathrm{~m}$, $1 \mathrm{H}), 8.02(\mathrm{~m}, 1 \mathrm{H}), 7.59-7.27(\mathrm{~m}, 4 \mathrm{H}), 4.36\left(\mathrm{t}, 2 \mathrm{H},=\mathrm{NCH}_{2^{-}}, \mathrm{J}=7.1 \mathrm{~Hz}\right), 3.50(\mathrm{t}, 2 \mathrm{H},-$ $\left.\mathrm{CH}_{2} \mathrm{Cl}, \mathrm{J}=6.4 \mathrm{~Hz}\right), 1.93(\mathrm{~m}, 2 \mathrm{H}), 1.74(\mathrm{~m}, 2 \mathrm{H}), 1.45(\mathrm{~m}, 4 \mathrm{H}) .{ }^{13} \mathrm{C}-\mathrm{NMR}(100 \mathrm{MHz}$, $\left.\mathrm{CDCl}_{3}\right): \delta 191.9,144.2,141.3,128.7,127.3,126.9,124.2,123.2,123.1,120.9,120.5$, 109.5, 109.0, 45.0, 43.4, 32.5, 29.0, 26.7, 26.6. HRMS (EI): $\mathrm{m} / \mathrm{z}=313.1227\left(\mathrm{M}^{+}\right), \Delta=2.1$ ppm.

N,N-Bis[4'-(6',-chlorohexyl)phenyl]-4-amino-benzaldhyde (6). 4, 4'Dibromotriphenylamine was synthesized according to the method reported previously. ${ }^{2} \mathrm{~A}$ solution containing 4,4'-dibromotriphenylamine $(1.9 \mathrm{~g}, 4.7 \mathrm{mmol})$ and an excess of dry 1,6dibromohexane $(11.5 \mathrm{~g}, 47 \mathrm{mmol})$ in $50 \mathrm{~mL}$ of dry THF was cooled down to $-78{ }^{\circ} \mathrm{C}$. tButyl lithium ( $8.3 \mathrm{~mL}$ of a $1.7 \mathrm{M}$ solution in pentane, 3 equiv.) was added dropwise and the reaction mixture was gradually allowed to reach room temperature for $4 \mathrm{hrs}$. The resulting solution was quenched with water, the solvent was removed under reduced pressure, and the residue extracted with dichloromethane. The organic phase was dried over magnesium sulfate and concentrated. Unreacted 1,6-dibromohexane was removed by vacuum distillation and bis[4-(6'-bromohexyl)phenyl]phenylamine was purified by column chromatography (dichloromethane/hexane $=1 / 10)$ in a colorless oil $(1.7 \mathrm{~g}, 63 \%)$. A 100 $\mathrm{mL}$ flask containing $20 \mathrm{~mL}$ of dry DMF was cooled down to $0{ }^{\circ} \mathrm{C}$. Phosphorous oxychloride $(0.75 \mathrm{~g}, 4.9 \mathrm{mmol})$ was added dropwise, while maintaining the temperature below $5{ }^{\circ} \mathrm{C}$. The reaction mixture was stirred for $30 \mathrm{~min}$. Bis[4-(6'bromohexyl)phenyl]phenylamine $(0.93 \mathrm{~g}, 1.62 \mathrm{mmol})$ in $10 \mathrm{~mL}$ of dry DMF was added to the above solution and the temperature was slowly increased to $90{ }^{\circ} \mathrm{C}$. After the reaction was heated overnight, it was cooled down to room temperature and poured into cold water. The $\mathrm{pH}$ of the solution was adjusted to around 7 with aqueous $\mathrm{NaOH}$ solution. The product was extracted with dichloromethane, dried over magnesium sulfate, and purified by silica gel column chromatography (ethyl acetate/hexane $=1 / 10$ ). The product yield was $0.65 \mathrm{~g}$ (78 \%). ${ }^{1} \mathrm{H}-\mathrm{NMR}\left(200 \mathrm{MHz}, \mathrm{CDCl}_{3}\right): \delta 9.78(\mathrm{~s}, 1 \mathrm{H},-\mathrm{CHO}), 7.65(\mathrm{~d}, 2 \mathrm{H}, \mathrm{J}=8.8 \mathrm{~Hz}), 7.15$ $(\mathrm{d}, 4 \mathrm{H}, \mathrm{J}=8.6 \mathrm{~Hz}), 7.08(\mathrm{~d}, 4 \mathrm{H}, \mathrm{J}=8.8 \mathrm{~Hz}), 6.95(\mathrm{~d}, 2 \mathrm{H}, \mathrm{J}=8.8 \mathrm{~Hz}), 3.55\left(\mathrm{t}, 4 \mathrm{H},-\mathrm{CH}_{2} \mathrm{Cl}, \mathrm{J}\right.$ $=6.7 \mathrm{~Hz}), 2.61\left(\mathrm{t}, 4 \mathrm{H}, \mathrm{ArCH}_{2^{-}}, \mathrm{J}=7.7 \mathrm{~Hz}\right), 1.80(\mathrm{~m}, 4 \mathrm{H}), 1.65(\mathrm{~m}, 4 \mathrm{H}), 1.44(\mathrm{~m}, 8 \mathrm{H}) .{ }^{13} \mathrm{C}-$ NMR (100 MHz, $\left.\mathrm{CDCl}_{3}\right): \delta 190.5,131.5,129.8,126.5,126.2,118.4,45.3,35.5,32.7,31.4$, 
28.7, 26.9. HRMS (EI): $\mathrm{m} / \mathrm{z}=509.2253\left(\mathrm{M}^{+}\right), \Delta=0.1 \mathrm{ppm}$.

\section{General Procedure for $1 \mathrm{~N} \sim \mathbf{3 N}$}

A $50 \mathrm{~mL}$ two-necked flask charged with 4,7,12,15-tetra-(diethylphosphonatemethyl)paracyclophane $(0.5 \mathrm{mmol})$ and 5eq. of aldehyde compound $(4 \sim 6,2.5 \mathrm{mmol})$ in $20 \mathrm{~mL}$ of dry THF was cooled down to $0{ }^{\circ} \mathrm{C}$ with an ice bath. To the above solution, $2.5 \mathrm{~mL}$ (5eq.) of potassium tert-butoxide (in THF, $1 \mathrm{M}$ ) was added dropwise at $0{ }^{\circ} \mathrm{C}$. The reaction mixture was stirred for $6 \mathrm{hrs}$ at $0{ }^{\circ} \mathrm{C}$ and was then quenched with water. The solvent was removed under reduced pressure and the resulting mixture was diluted with dichloromethane, washed with water and brine, and dried over magnesium sulfate. The crude compound was purified by silica gel column chromatography.

4,7,12,15-Tetra[N,N-bis(6'"-chlorohexyl)-4'-aminostyryl]-[2.2]paracyclophane (1N). The crude product was purified by silica gel column chromatography (chloroform/hexane = 1/1) to give $1 \mathrm{~N}$ in $60 \%$ yield. ${ }^{1} \mathrm{H}-\mathrm{NMR}\left(400 \mathrm{MHz}, \mathrm{CDCl}_{3}\right)$ : $\delta 7.41(\mathrm{~d}, 8 \mathrm{H}, \mathrm{J}=8.6 \mathrm{~Hz}), 6.99$ $(\mathrm{d}, 4 \mathrm{H},-\mathrm{CH}=\mathrm{CH}-, \mathrm{J}=15.6 \mathrm{~Hz}), 6.96(\mathrm{~s}, 4 \mathrm{H}), 6.86(\mathrm{~d}, 4 \mathrm{H},-\mathrm{CH}=\mathrm{CH}-, \mathrm{J}=15.6 \mathrm{~Hz}), 6.67$ (d, $8 \mathrm{H}, \mathrm{J}=8.6 \mathrm{~Hz}), 3.57\left(\mathrm{t}, 16 \mathrm{H},-\mathrm{CH}_{2} \mathrm{Cl}, \mathrm{J}=6.6 \mathrm{~Hz}\right), 3.51(\mathrm{~m}, 4 \mathrm{H}$, bridge proton of $\mathrm{pCp}), 3.34$ (br m, 16H, - $\mathrm{NCH}_{2^{-}}$), $2.84(\mathrm{~m}, 4 \mathrm{H}$, bridge proton of $\mathrm{pCp}), 1.83(\mathrm{~m}, 16 \mathrm{H}), 1.67(\mathrm{~m}, 16 \mathrm{H})$, $1.53(\mathrm{~m}, 16 \mathrm{H}), 1.41(\mathrm{~m}, 16 \mathrm{H}) .{ }^{13} \mathrm{C}-\mathrm{NMR}\left(100 \mathrm{MHz}, \mathrm{CDCl}_{3}\right): \delta 147.7,137.3,136.8,128.2$, $127.6,125.8,121.6,112.0,51.2,45.3,33.4,32.8,27.5,27.0,26.7$. MS (FAB): $\mathrm{m} / \mathrm{z}=1626$ $\left(\mathrm{M}^{+}\right)$

4,7,12,15-Tetra[(N-(6'-chlorohexyl)carbazol-3'-yl)vinyl]-[2.2]paracyclophane $(2 \mathrm{~N})$. The compound was purified by column chromatography (dichloromethane/hexane $=1 / 2$ ) in $60 \%$ yield. ${ }^{1} \mathrm{H}-\mathrm{NMR}\left(200 \mathrm{MHz}, \mathrm{CDCl}_{3}\right): \delta 8.14(\mathrm{~s}, 4 \mathrm{H}), 7.86(\mathrm{~m}, 8 \mathrm{H}), 7.53-7.30(\mathrm{~m}$, $20 \mathrm{H}), 7.23(\mathrm{~s}, 4 \mathrm{H}), 7.05(\mathrm{~m}, 4 \mathrm{H}), 4.37\left(\mathrm{t}, 8 \mathrm{H},=\mathrm{NCH}_{2^{-}}, \mathrm{J}=6.9 \mathrm{~Hz}\right), 3.75(\mathrm{~m}, 4 \mathrm{H}$, bridge proton of pCp), $3.50\left(\mathrm{t}, 8 \mathrm{H},-\mathrm{CH}_{2} \mathrm{Cl}, \mathrm{J}=6.5 \mathrm{~Hz}\right), 3.08(\mathrm{~m}, 4 \mathrm{H}$, bridge proton of $\mathrm{pCp}), 1.96$ $(\mathrm{m}, 8 \mathrm{H}), 1.75(\mathrm{~m}, 8 \mathrm{H}), 1.47(\mathrm{~m}, 16 \mathrm{H}) .{ }^{13} \mathrm{C}-\mathrm{NMR}\left(100 \mathrm{MHz}, \mathrm{CDCl}_{3}\right): \delta 141.0,140.3,137.7$, 137.1, 129.8, 129.5, 128.0, 126.0, 124.3, 123.4, 123.1, 120.9, 119.8, 119.6, 119.2, 109.3, $108.9,45.2,43.2,33.4,32.6,29.1,26.8 . \mathrm{MS}(\mathrm{FAB}): \mathrm{m} / \mathrm{z}=1447\left(\mathrm{M}^{+}\right)$.

4,7,12,15-Tetra[N,N-bis(4"'-(6"',-chlorohexyl)phenyl)-4'-aminostyryl]-

[2.2]paracyclophane (3N). The compound was purified by column chromatography (dichloromethane/hexane $=1 / 3)$ in $61 \%$ yield. ${ }^{1} \mathrm{H}-\mathrm{NMR}\left(200 \mathrm{MHz}, \mathrm{CDCl}_{3}\right): \delta 7.36(\mathrm{~d}, 8 \mathrm{H}$, $\mathrm{J}=8.6 \mathrm{~Hz}), 7.2-7.0(\mathrm{~m}, 48 \mathrm{H}), 6.90(\mathrm{~d}, 4 \mathrm{H},-\mathrm{CH}=\mathrm{CH}-, \mathrm{J}=16 \mathrm{~Hz}), 3.56(\mathrm{t}$ and br, 20H, $\mathrm{CH}_{2} \mathrm{Cl}(\mathrm{J}=6.7 \mathrm{~Hz})$ and bridge proton of $\left.\mathrm{pCp}\right), 2.88(\mathrm{br}, 4 \mathrm{H}$, bridge proton of $\mathrm{pCp}), 2.60(\mathrm{t}$, $\left.16 \mathrm{H}, \mathrm{ArCH}_{2^{-}}, \mathrm{J}=7.6 \mathrm{~Hz}\right), 1.82(\mathrm{~m}, 16 \mathrm{H}), 1.66(\mathrm{~m}, 16 \mathrm{H}), 1.46(\mathrm{~m}, 32 \mathrm{H}) .{ }^{13} \mathrm{C}-\mathrm{NMR}(100$ $\left.\mathrm{MHz}, \mathrm{CDCl}_{3}\right): \delta 147.7,145.5,137.7,137.5,136.8,131.6,129.3,128.1,127.5,124.6,123.8$, 123.2, 45.3, 35.4, 33.4, 32.7, 31.5, 28.8, 26.9. $\mathrm{MS}(\mathrm{FAB}): \mathrm{m} / \mathrm{z}=2234\left(\mathrm{M}^{+}\right)$.

General Procedure for $1 \mathrm{C} \sim 3 \mathrm{C}$

A round-bottomed flask was charged with $0.1 \mathrm{mmol}$ of $\mathbf{1 N} \sim \mathbf{3 N}$ in $5 \mathrm{~mL}$ of dry dichloromethane and a large excess of sodium iodide $(30 \mathrm{mmol})$ in $200 \mathrm{~mL}$ of dry acetone. 
The reaction solution was heated to reflux for 2 days. The solvent was then removed under reduce pressure and the residue was diluted with dichloromethane, washed with brine, and dried over anhydrous magnesium sulfate. The crude compound was purified by column chromatography in $70-80 \%$ yield. After the chloride/iodide exchange, to a solution of each compound $(0.05 \mathrm{mmol})$ in $20 \mathrm{~mL}$ of THF, was added an excess of condensed trimethylamine $(2 \mathrm{~mL})$ using a dry ice/acetone filled gas condenser at $-78^{\circ} \mathrm{C}$. The reaction mixture was allowed to slowly warm up to room temperature and was stirred for $12 \mathrm{hrs}$. A small amount of water was added to the above solution to dissolve the precipitated compounds and the reaction solution was cooled down to $-78{ }^{\circ} \mathrm{C}$. An excess of condensed trimethylamine $(2 \mathrm{~mL})$ was added again and the resulting solution was allowed to reach room temperature and stirred for additional $12 \mathrm{hrs}$. After the reaction was completed, excess trimethylamine and solvent were removed under reduced pressure. The remaining water solution was washed with diethyl ether and chloroform, and finally water was removed by vacuum distillation. A crude product was dissolved in a minimum amount of hot methanol and precipitated into diethyl ether several times.

4,7,12,15-Tetra[N,N-bis(6'-(N,N,N-trimethylammonium)hexyl)-4'-aminostyryl][2.2]paracyclophane octaiodide (1C). Yield: $85 \% .{ }^{1} \mathrm{H}-\mathrm{NMR}\left(400 \mathrm{MHz}, \mathrm{DMSO}-\mathrm{d}_{6}\right): \delta$ 7.37 (d, 8H, J = 8.8 Hz), 6.98 (d, 4H, $-\mathrm{CH}=\mathrm{CH}-, \mathrm{J}=16.0 \mathrm{~Hz}), 6.80(\mathrm{~s}, 4 \mathrm{H}), 6.69(\mathrm{~m}, 12 \mathrm{H})$, 3.53 (br m, 4H, bridge proton of pCp), $3.35(\mathrm{~m}, 32 \mathrm{H}), 3.07\left(\mathrm{~s}, 72 \mathrm{H},-\mathrm{N}^{+}\left(\mathrm{CH}_{3}\right)_{3} \mathrm{I}^{-}\right), 2.73(\mathrm{br}$ $\mathrm{m}, 4 \mathrm{H}$, bridge proton of $\mathrm{pCp}), 1.70(\mathrm{br} \mathrm{m}, 16 \mathrm{H}), 1.59$ (br m, $16 \mathrm{H}), 1.37(\mathrm{br} \mathrm{m}, 32 \mathrm{H}) .{ }^{13} \mathrm{C}-$ NMR (100 MHz, DMSO-d 6 ): $\delta$ 147.3, 136.9, 136.3, 127.9, 127.0, 124.6, 120.9, 111.7, 65.2, $52.2,50.1,32.7,26.8,26.1,25.8,22.2$. MS (ESI/TOF): $1287.6\left(\mathrm{M}^{2+}-2 \mathrm{I}\right), 816.1\left(\mathrm{M}^{3+}-3 \mathrm{I}\right)$, $580.3\left(\mathrm{M}^{4+}-4 \mathrm{I}\right)$.

4,7,12,15-Tetra[(N-(6''-(N,N,N-trimethylammonium)hexyl)carbazol-3'-yl)vinyl][2.2]paracyclophane octaiodide (2C). Yield: $90 \%$. ${ }^{1} \mathrm{H}-\mathrm{NMR}\left(200 \mathrm{MHz}, \mathrm{DMSO}-\mathrm{d}_{6}\right): \delta$ $8.13(\mathrm{~s}, 4 \mathrm{H}), 7.93(\mathrm{~d}, 4 \mathrm{H}, \mathrm{J}=8.8 \mathrm{~Hz}), 7.70(\mathrm{~m}, 12 \mathrm{H}), 7.43(\mathrm{~m}, 8 \mathrm{H}), 7.14(\mathrm{~d}, 4 \mathrm{H},-\mathrm{CH}=\mathrm{CH}-$, $\mathrm{J}=16 \mathrm{~Hz}), 7.09(\mathrm{~s}, 4 \mathrm{H}), 6.93(\mathrm{~m}, 4 \mathrm{H}), 4.49\left(\mathrm{br}, 8 \mathrm{H},=\mathrm{NCH}_{2^{-}}\right), 3.73(\mathrm{br}, 4 \mathrm{H}$, bridge proton of pCp), $3.21\left(\mathrm{~m}, 8 \mathrm{H},-\mathrm{CH}_{2} \mathrm{~N}^{+}\left(\mathrm{CH}_{3}\right)_{3} \mathrm{I}^{-}\right), 2.99\left(\mathrm{~s}, 40 \mathrm{H},-\mathrm{N}^{+}\left(\mathrm{CH}_{3}\right)_{3} \mathrm{I}^{-}\right.$and bridge proton of pCp), 1.86 (br, 8H), 1.58 (br, 8H), 1.33 (br, 16H). ${ }^{13} \mathrm{C}-\mathrm{NMR}(100 \mathrm{MHz}$, DMSO-d 6 ): $\delta$ 140.4, 139.7, 137.5, 136.9, 129.6, 128.9, 127.7, 125.9,124.2, 123.5, 122.5, 122.1, 120.3, $119.5,118.8,109.8,109.5,65.3,52.1,42.3,32.6,28.5,26.1,25.7,22.1$. MS (ESI/TOF): $\mathrm{m} / \mathrm{z}=897\left(\mathrm{M}^{2+}-2 \mathrm{I}\right), 556\left(\mathrm{M}^{3+}-3 \mathrm{I}\right), 385\left(\mathrm{M}^{4+}-4 \mathrm{I}\right)$.

4,7,12,15-Tetra[N,N-bis(4"'-(6"'-(N,N,N-trimethylammonium)hexyl)phenyl)-4'aminostyryl]-[2.2]paracyclophane octaiodide (3C). Yield: $90 \%$. ${ }^{1} \mathrm{H}-\mathrm{NMR}(200 \mathrm{MHz}$, DMSO-d $\left.\mathrm{d}_{6}\right): \delta 7.39(\mathrm{~d}, 8 \mathrm{H}, \mathrm{J}=8.4 \mathrm{~Hz}), 7.17(\mathrm{~d}, 4 \mathrm{H},-C H=C H-, \mathrm{J}=13.8 \mathrm{~Hz}), 7.12(\mathrm{~d}, 16 \mathrm{H}, \mathrm{J}$ $=8.6 \mathrm{~Hz}), 6.94(\mathrm{~d}, 16 \mathrm{H}, \mathrm{J}=8.4 \mathrm{~Hz}), 6.9-6.82(\mathrm{~m}, 12 \mathrm{H}), 6.76(\mathrm{~d}, 4 \mathrm{H},-C H=C H-, \mathrm{J}=13.8$ $\mathrm{Hz}), 3.55\left(\mathrm{br}, 4 \mathrm{H}\right.$, bridge proton of pCp), $3.27\left(\mathrm{~m}, 16 \mathrm{H},-\mathrm{CH}_{2} \mathrm{~N}^{+}\left(\mathrm{CH}_{3}\right)_{3} \mathrm{I}^{-}\right), 3.05(\mathrm{~s}, 72 \mathrm{H},-$ $\left.\mathrm{N}^{+}\left(\mathrm{CH}_{3}\right)_{3} \mathrm{I}^{-}\right), 2.84$ (br, 4H, bridge proton of $\mathrm{pCp}$ ), $2.52(\mathrm{br}, 16 \mathrm{H}), 1.63(\mathrm{br}, 32 \mathrm{H}), 1.34(\mathrm{br}$, $32 \mathrm{H}) .{ }^{13} \mathrm{C}-\mathrm{NMR}\left(100 \mathrm{MHz}, \mathrm{DMSO}-\mathrm{d}_{6}\right): \delta 146.9,144.8,137.5,137.2,136.6,131.2,129.3$, $128.1,127.8,124.1,123.7,122.4,65.3,52.2,34.5,32.4,30.8,28.4,25.7,22.1$. MS (ESI): 
$\mathrm{m} / \mathrm{z}=1019\left(\mathrm{M}^{3+}-3 \mathrm{I}\right), 732\left(\mathrm{M}^{4+}-4 \mathrm{I}\right), 560\left(\mathrm{M}^{5+}-5 \mathrm{I}\right), 446\left(\mathrm{M}^{6+}-6 \mathrm{I}\right)$.

\section{Two-Photon Absorption Measurements}

Two-photon absorption (TPA) spectra were measured using two-photon induced fluorescence (TPIF) spectroscopy. ${ }^{3}$ The samples are excited via TPA process by directing a tightly collimated, high intensity laser beam on the sample (Figure 1). The emission from the sample was collected at a $90^{\circ}$ angle by a high numerical aperture lens and directed to a spectrometer's entrance slit. The radiation dispersed by the spectrometer was detected by a thermoelectrically cooled charge coupled device (CCD) camera (Roper Scientific Spec10:100B/TE). Excitation pulses with typical duration of $90 \mathrm{fs}$ and energy of $\sim 6 \mathrm{~nJ}$ within the spectral range $700-1000 \mathrm{~nm}$ were produced by the mode-locked Ti:Sapphire laser (Spectraphysics Tsunami) with a repetition rate of $82 \mathrm{MHz}$. For the spectral range 620 - $700 \mathrm{~nm}$, femtosecond optical parametric amplifier (OPA) was used. Signal output of the OPA (Spectraphysics OPA-800C) was upconverted into the visible range of spectrum using the second harmonic generation (SHG) process in $\beta$-barium borate crystal, which yielded $120 \mathrm{fs}$ pulses with energy of $\sim 30 \mu \mathrm{J}$ and a repetition rate of $1 \mathrm{kHz}$. A neutral density filter wheel was used to attenuate the energy of the laser pulses down to the desirable level.

Two-photon induced PL spectra of a standard and the samples were recorded at the same excitation wavelength. The ratio of the integrated PL intensities for the reference and the sample can be expressed as:

$$
\frac{I}{I_{\text {ref }}}=\frac{\eta \delta c}{\eta_{\text {ref }} \delta_{\text {ref }} c_{\text {ref }}} \frac{P^{2}}{P_{r e f}^{2}} K
$$

Here, the index ref denotes values related to the reference measurements. The signal intensity collected by detector is denoted as $I$ and $\eta$ is the fluorescence quantum yield. The number density of the molecules in solution is denoted as $c . \delta_{\text {ref }}$ means the TPA cross section of the reference molecule. Also, we assume that all experimental parameters were identical during the series of measurements, except the power of the pump radiation $(P)$ and sample specific parameters, $\eta$ and $c . K$ is a correction factor that takes into account the difference in refractive indices of the solvents of the samples and the reference material. It depends on the excitation beam geometry. In our case of nearly-collimated beams, $K=n_{\text {ref }}$ $2 / n^{2}$.

Molar concentrations of the compounds were determined from optical absorption spectra, using molar absorptivity values supplied by the compound manufacturer or obtained from volumetric measurements. In all measurements, the concentration of the chromophores was adjusted around $10^{-5} \mathrm{M}$, to avoid emission self-quenching. Fluorescence quantum yields were measured relative to fluorescein and verified using a referenceless technique described previously. ${ }^{4}$ Absorption and emission spectra of samples were monitored. Being properly degassed, our samples did not exhibit any sign of degradation within the timescale of the measurements.

As reference materials in the spectral range of $700-900 \mathrm{~nm}$, we used three laser 
dyes: Coumarin 503 (aka Coumarin 307, purchased from Exciton Inc.), Fluorescein (purchased from Acros Inc.), and Rhodamine 610 (aka Rhodamine B, purchased from Exciton Inc.). Coumarin 503 and Rhodamine 610 were dissolved in methanol, and fluorescein was prepared in water $(\mathrm{pH}=11)$. $p$-Bis $(o$-methylstyryl $)$ benzene in cyclohexane $\left(10^{-4} \mathrm{M}\right)$ was used as a reference for measurements in the spectral range below $700 \mathrm{~nm}$. TPIF studies were performed in a low excitation power regime, which was verified by measuring the quadratic dependence of the TPIF signal on the laser pump intensity.

The TPA of $\mathbf{1 N}, \mathbf{2 N}$, and $\mathbf{3 N}$ were measured in toluene, while $\mathbf{1 C}, \mathbf{2 C}$ and $\mathbf{3 C}$ were studied in water (Figure 2). The absorption and emission spectra of the $\mathbf{N}$ and $\mathbf{C}$ series were measured in DMSO and were shown to be nearly identical (Figure 3). 
$\underset{\mathrm{K}_{2} \mathrm{CO}_{3}, \mathrm{n} \text {-Butanol }}{\mathrm{HO}\left(\mathrm{CH}_{2}\right)_{6} \mathrm{Cl}}$

4
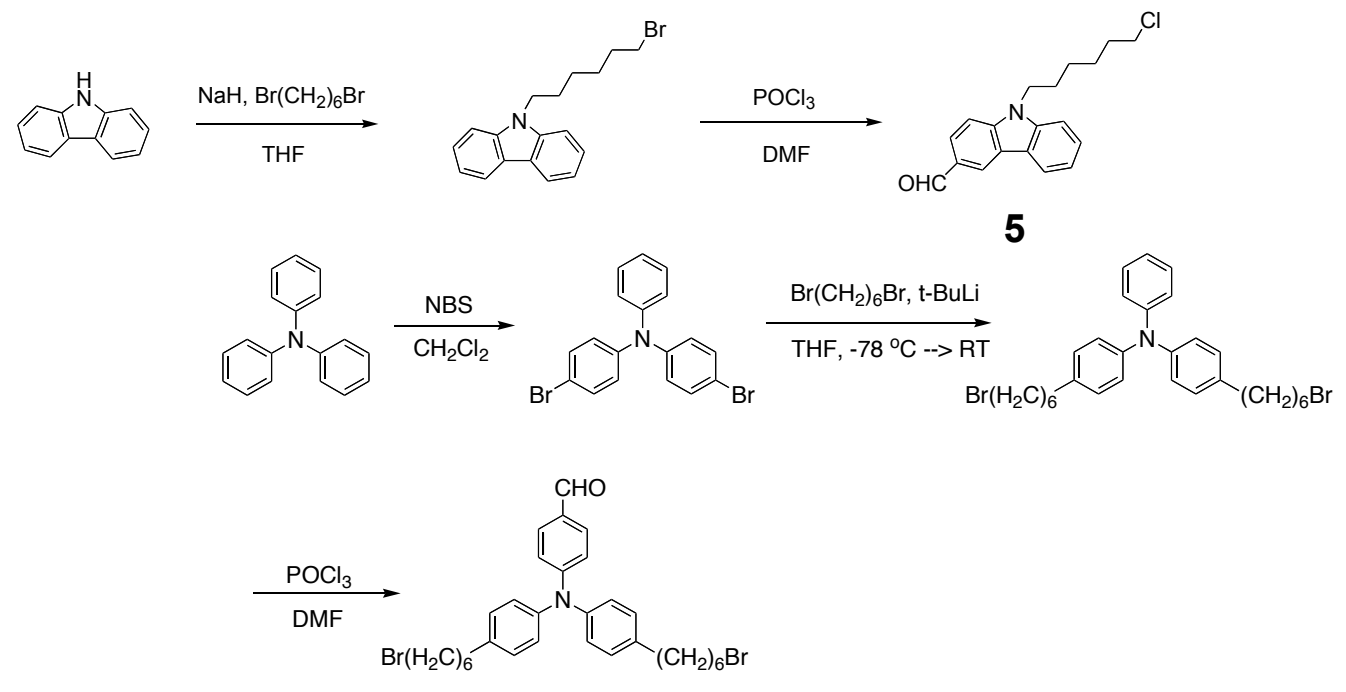

6

Scheme 1. Synthetic routes to $\mathbf{4 , 5}$, and $\mathbf{6}$.

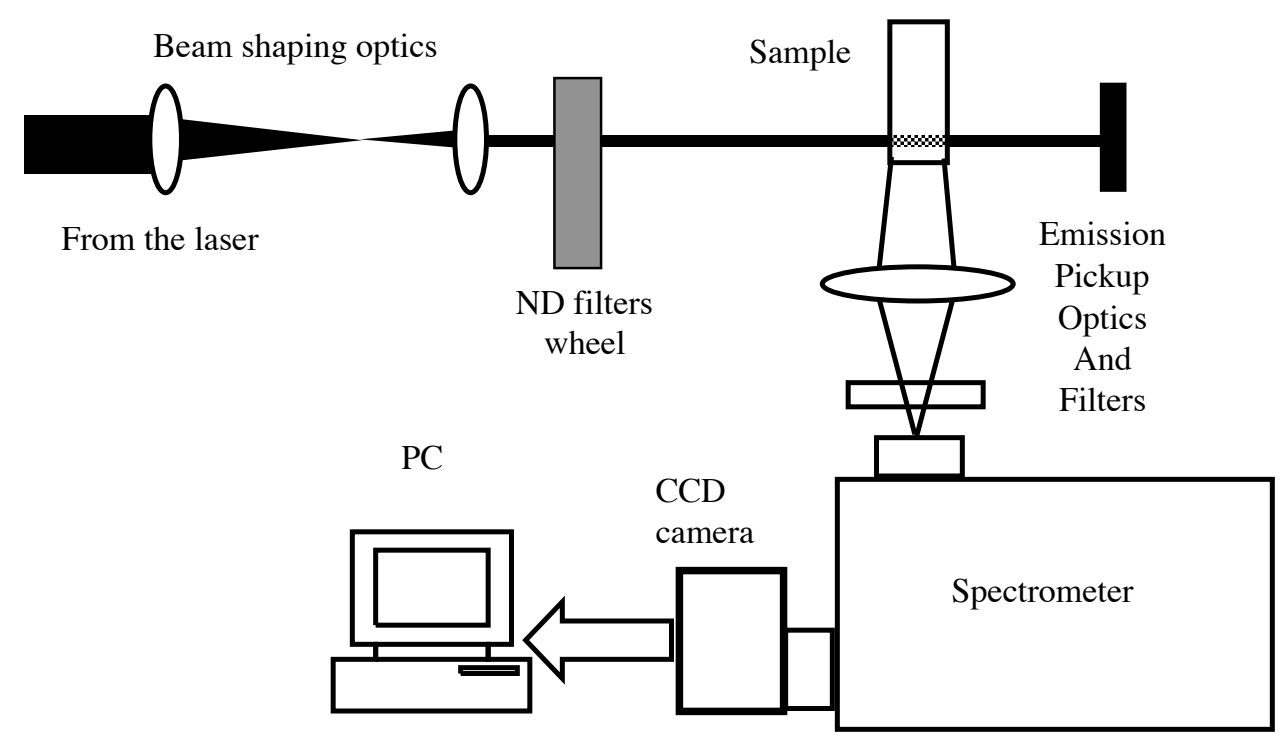

Figure 1. Experimental setup for the TPA cross section measurements. 


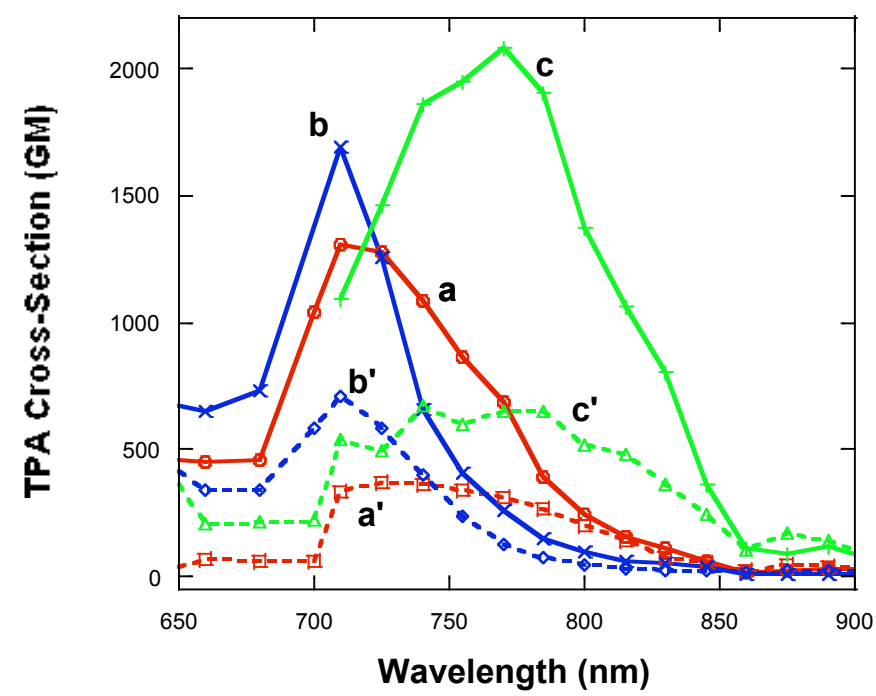

Figure 2. Two-photon absorption spectra of $\mathbf{1 N}$ (a), $\mathbf{2 N}$ (b) and $\mathbf{3 N}$ (c) in toluene and $\mathbf{1 C}$ $\left(a^{\prime}\right), 2 C\left(b^{\prime}\right)$ and $3 C$ (c') in water.

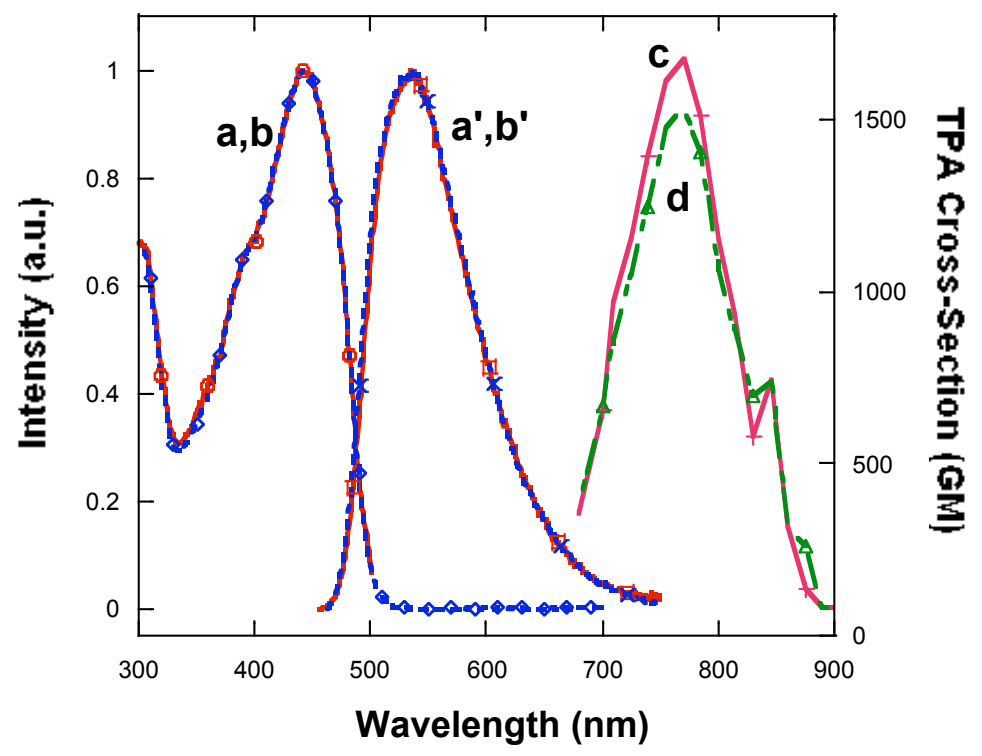

Figure 3. Normalized absorption and emission spectra of $\mathbf{3 N}$ (a, a': red solid line) and $\mathbf{3 C}$ (b,b':blue dotted line) in DMSO. Two-photon absorption spectra of $\mathbf{3 N}(\mathrm{c})$ and $\mathbf{3 C}$ (d) in DMSO.

\section{References}


${ }^{1}$ Moon, K. -J.; Shim, H. -K.; Lee, K. -S.; Zieba, J.; Prasad, P. N. Macromolcules 1996, 29, 861.

${ }^{2}$ Lee, H. J.; Sohn, J.; Hwang, J.; Park, S. Y.; Choi, H.; Cha, M. Chem. Mater. 2004, 16, 456.

${ }^{3}$ Xu, C.; Webb, W. W. J. Opt. Soc. Am. B 1996, 13, 481.

${ }^{4}$ Greenham, N. C.; Samuel, I. D. W.; Hayes, G. R.; Phillips, R. T.; Kessener, Y. A. R. R.;

Moratti, S. C.; Homes, A. B.; Friend, R. H. Chem. Phys. Lett. 1995, $241,89$. 